\title{
PHARMACOLOGICAL ACTIVITY OF ULVA LACTUCA POLYPHENOLS FRACTION: HEPATOPROTECTIVE AND ANTIOXIDANT ACTIVITIES AGAINST PARACETAMOL-INDUCED LIVER DAMAGE IN RATS
}

\author{
RAVINDRAN NT*, MOHAMED SADIQ A \\ Department of Biochemistry, Adhiparasakthi College of Arts and Science (Autonomous), Kalavai, Tamil Nadu, India. \\ Email: ntraveendiran@gmail.com
}

Received: 06 December 2018, Revised and Accepted: 01 February 2019

\section{ABSTRACT}

Objective: The objective of this study was to assess the activity Ulva lactuca polyphenols fraction in protecting the liver damage induced by high dose of paracetamol.

Methods: This study was performed using Wistar albino rats divided into six groups. Group 1 was the normal group. Groups 2, 3, 4, 5, and 6 received paracetamol $(2 \mathrm{~g} / \mathrm{kg})$ for 7 days. In addition to paracetamol, Groups 3, 4, 5, and 6 received silymarin $(100 \mathrm{mg} / \mathrm{kg}), U$. lactuca polyphenols fraction at the doses of 50,100 , and $200 \mathrm{mg} / \mathrm{kg}$, respectively, for 7 days. On the $8^{\text {th }}$ day, serum and liver samples were collected from the animals and the hepatoprotective and antioxidant activities were assessed by studying the levels of liver marker enzymes, bilirubin, protein, reduced glutathione, and antioxidant enzymes.

Results: U. lactuca polyphenols fraction, at the tested doses, restored the levels of all serum markers and enzymes (aspartate aminotransferase, alanine aminotransferase, alkaline phosphatase, lactate dehydrogenase, $\gamma$-glutamyl transferase, total bilirubin, total protein, cholesterol, triglycerides, and reduced glutathione) and liver homogenate markers (reduced glutathione, superoxide dismutase, catalase, and glutathione peroxidase) significantly, in dose-dependent manner.

Conclusion: This study suggests that $U$. lactuca polyphenols fraction has a hepatoprotective effect against paracetamol-induced liver damage and possesses antioxidant activities.

Keywords: Hepatoprotective activity, Antioxidant activity, Paracetamol, Marine alga, Edible alga, Ulva lactuca, Polyphenols fraction.

(c) 2019 The Authors. Published by Innovare Academic Sciences Pvt Ltd. This is an open access article under the CC BY license (http://creativecommons. org/licenses/by/4. 0/) DOI: http://dx.doi.org/10.22159/ajpcr.2019.v12i4.31214

\section{INTRODUCTION}

Liver is an essential organ which is involved in detoxification of the exogenous xenobiotics, drugs and endogenous bile pigments, viral infections, and chronic alcoholism. While performing several detoxifications, liver is subjected to stress, leading to liver diseases resulting in liver damage and serious health problems and death. The liver regulates many important metabolic functions. Hepatic injury is associated with distortion of these metabolic functions [1]. Liver damage is a common pathology, which in most cases, involves oxidative stress and is characterized by a progressive evolution from steatosis to chronic hepatitis, fibrosis, cirrhosis, and hepatocellular carcinoma [2]. As oxidative stress plays a central role in liver pathologies and their development, the use of antioxidants has been proposed as therapeutic agents to counteract liver damage.

In spite of advancements in modern medicine, hepatoprotective drugs are quite limited. The extended usage of remedies available in modern medicine is associated with severe side effects. The development or detection of new molecules effective in treating or preventing hepatic damage remains a challenge in the field of drug development [3]. It is generally recognized that indigenous drugs used traditionally by ethnic tribes or societies across the world can provide relief to patients with hepatic disorders. As a result, a conscious effort is undertaken to screen indigenous drugs used traditionally in different regions of the world, especially India and China. Plant-based drugs exhibiting hepatoprotective and antioxidant activities have been isolated from many species. A well-known potential hepatoprotective drug is, silymarin, isolated from Silybum marianum.
In recent times, the pharmaceutical and agri-food industries have been responsible for a great expansion in the demand for marine alga due to their significant applications as ingredients in functional foods and richness in antioxidant ingredients. It has been reported that marine alga are rich source of bioactive compounds such as terpenoids, phlorotannins, fucoidans, sterols and glycolipids, and the extracts or isolated pure components from marine alga possess a wide range of pharmacological properties such as anticancer, antibacterial, antifungal, antiviral, anti-inflammatory, anticoagulant, antioxidant, hypoglycemic, hypolipidemic, antimelanogenic, hepatoprotective, and neuroprotective activities $[4,5]$. Apart from these, marine alga are also a rich resource of dietary iodine and fibers which can also play a major role in improving the nutritional quality [6].

The green marine alga Ulva lactuca, commonly known as sea lettuce, has long been used as food and as a traditional medicinal agent to treat helminthic infections, fever, urinary diseases, and dropsy [7]. U. actuca is rich in flavonoids and has potent antioxidant properties [8]. The hepatoprotective nature of $U$. lactuca against liver injury induced by D-galactosamine/endotoxin in rats has been established [9]. U. lactuca has also been shown to have potent hypocholesterolemic and antioxidant effects [10], antibacterial activity [11], nephroprotective activity [12], neuroprotective activity [13], and alpha-amylase and alpha-glucosidase inhibitory activity [14].

In view of these reports, the present investigation has been undertaken to evaluate the hepatoprotective and antioxidant activities of the polyphenols fraction of U. lactuca against paracetamol intoxicated liver damage in rat. Marine alga U. lactuca was selected for the present study 
as it is an edible marine alga, easily available in the Gulf of Mannar Coast of Mandapam.

\section{MATERIALS AND METHODS}

\section{Collection of marine alga sample}

Fresh marine alga $U$. lactuca was collected from the intertidal regions of the Mandapam coast of Gulf of Mannar. The taxonomic identification of species was done using standard literature and taxonomic keys. The alga was identified and authenticated by the Principal Scientist, Central Salt and Marine Chemical Research Institute, Mandapam Camp. The collected samples were cleaned well with the seawater until unnecessary impurities, adhering sand particles, and extraneous matter such as epiphytes, pebbles, and shells were removed, and it was brought to the laboratory in sterile plastic bags containing seawater to prevent evaporation. It was then washed thoroughly with tap water and distilled water to remove the surface salty materials. It was air dried for 1 week and later ground in an electric mixer. The powdered samples were subsequently stored in the refrigerator for future use.

\section{Extraction of polyphenols fraction from $\boldsymbol{U}$. lactuca}

The powdered samples were then extracted with $80 \%$ ethanol for $24 \mathrm{~h}$ under continuous shake at $20^{\circ} \mathrm{C}$. The extracts were then concentrated in a rotary evaporator under reduced pressure at $40^{\circ} \mathrm{C}$ [15]. The solid mass obtained was stored at $4^{\circ} \mathrm{C}$. At the time of administration to the rats, the polyphenols fraction was dissolved in distilled water to required concentration.

\section{Experimental animals}

Male Swiss albino mice weighing 20-25 g and male Wistar albino rats weighing 150-200 g were used for the study. The animals were maintained in well-ventilated rooms with 12:12 light/dark cycle, $24 \pm 2{ }^{\circ} \mathrm{C}$ temperature, and $30-70 \%$ relative humidity, in polypropylene cages. Standard rat rodent pellets (M/s. Hindustan Lever Ltd., Mumbai) and water were provided ad libitum. Animals were acclimatized to the laboratory conditions 1 week before the initiation of the study. The study was approved by the Institutional Animal Ethical Committee (IAEC) constituted for the purpose of CPCSEA (IAEC/APCAS/01/2015/01).

\section{Acute toxicity studies}

Acute oral toxicity was performed according to OECD-423 guidelines [16]. Male Swiss albino mice weighing 20-25 g selected by random sampling technique were used in the study. The animals were fasted overnight, provided only water after which polyphenols fraction was administered to the groups (3 mice/group) orally at the dose level of $5 \mathrm{mg} / \mathrm{kg}$ body weight by gastric intubation and the groups were observed for 14 days. If mortality was observed in 2 or 3 animals, then the dose administered was considered as a toxic dose. However, if mortality was observed in one animal, then the same dose was repeated again to confirm the toxic dose. If no mortality was observed, then higher (50,300, and $2000 \mathrm{mg} / \mathrm{kg}$ ) doses of polyphenol fraction were employed for further toxicity studies. The animals were observed for toxic symptoms such as behavioral changes, locomotion, convulsions, and mortality.

\section{Induction of hepatic damage}

Liver damage was induced in rats by paracetamol (acetaminophen) suspended in $0.5 \%$ Tween- 80 and administered p.o., at a dose of $2 \mathrm{~g} / \mathrm{kg}$ body weight.

\section{Experimental design}

Male Wistar albino rats (male) weighing between 150 and 200 g were divided into six groups of six animals each. The weight range of the animals was equally distributed throughout the groups.

- Group 1: Control rats received distilled water orally for 7 days.

- Group 2: Treated with paracetamol $(2 \mathrm{~g} / \mathrm{kg})$ for 7 days.

- Group 3: Treated with paracetamol $(2 \mathrm{~g} / \mathrm{kg})$ and silymarin $(100 \mathrm{mg} / \mathrm{kg})$ dissolved in water for 7 days.

- Group 4: Treated with paracetamol $(2 \mathrm{~g} / \mathrm{kg})$ and U. lactuca polyphenols fraction $(50 \mathrm{mg} / \mathrm{kg})$ dissolved in water for 7 days.
- Group 5: Treated with paracetamol $(2 \mathrm{~g} / \mathrm{kg})$ and U. lactuca polyphenols fraction $(100 \mathrm{mg} / \mathrm{kg})$ dissolved in water for 7 days.

- Group 6: Treated with paracetamol $(2 \mathrm{~g} / \mathrm{kg})$ and U. lactuca polyphenols fraction $(200 \mathrm{mg} / \mathrm{kg})$ dissolved in water for 7 days.

Animals were kept starved overnight on the $7^{\text {th }}$ day. The next day, all the animals were sacrificed under light ether anesthesia. Blood was collected by direct cardiac puncture into sterilized dry centrifuge tubes and allowed to coagulate for $30 \mathrm{~min}$ at $37^{\circ} \mathrm{C}$. The clear serum was separated at $2500 \mathrm{rpm}$ for $10 \mathrm{~min}$ and subjected to various biochemical estimations. $100 \mathrm{mg}$ of liver issue from each rat was used for antioxidant study.

\section{Biochemical estimations}

The separated serum was subjected to biochemical estimation of different parameters such as alanine aminotransferase (ALT), aspartate aminotransferase (AST) [17], alkaline phosphatase (ALP) [18], lactate dehydrogenase (LDH) [19], $\gamma$-glutamyl transferase $(\gamma$-GT) [20], total bilirubin [21], total protein [22], cholesterol [23], triglycerides [24], and reduced glutathione [25].

\section{The antioxidant status}

One hundred milligram of liver tissue was weighed and homogenate was prepared in $10 \mathrm{ml}$ Tris-hydrochloric acid buffer (0.5 M; pH 7.4) at $4^{\circ} \mathrm{C}$. The homogenate was centrifuged and the supernatant was used for the estimation of reduced glutathione [25] and assay of antioxidant enzymes such as superoxide dismutase [26], catalase [27], and glutathione peroxidase [28].

\section{Statistical analysis}

One-way analysis of variance followed by Dunnett's t-test was applied for determining the statistical significance of difference between experimental groups. $p<0.05$ was considered to be statistically significant.

\section{RESULTS AND DISCUSSION}

All the doses $(5,50,300$, and $2000 \mathrm{mg} / \mathrm{kg}$ ) of $U$. lactuca polyphenols fraction tested for acute oral toxicity studies were found to be non-toxic. According to the OECD-423 guidelines for acute oral toxicity, the $\mathrm{LD}_{50}$ dose of $2000 \mathrm{mg} / \mathrm{kg}$ and above is categorized as unclassified. U. lactuca polyphenols fraction did not produce any mortality even at the highest dose $(2000 \mathrm{mg} / \mathrm{kg})$ employed, and hence, U. lactuca polyphenols fraction was considered to be safe for further pharmacological screening. Three submaximal doses $(50,100$, and $200 \mathrm{mg} / \mathrm{kg})$ were employed for further pharmacological investigations.

Liver is the largest organ and is a target for toxicity due to its role in clearing and metabolizing chemicals through the process of detoxification [29]. Drug-induced liver disorders occurring frequently can be life threatening and mimic all forms of liver diseases [30]. Paracetamol is also a drug which is capable of causing liver disorders, if it is given continuously.

The paracetamol-induced liver disorders were treated with $U$. lactuca polyphenols fraction for 7 days. Estimating the activities of serum marker enzymes such as AST, ALT, ALP, $\gamma$-GT, and LDH is a tool for the assessment of the liver function. When the liver cell plasma membrane is damaged, a variety of enzymes normally located in the cytosol are released into the bloodstream. Their estimation is a useful quantitative marker of the extent and type of hepatocellular damage identification [31]. An obvious sign of hepatic injury is the leakage of cellular enzymes such as AST, ALT, and ALP [32].

There was a significant increase $(\mathrm{p}<0.01)$ in the levels of AST, ALT, ALP, LDH, $\gamma$-GT, total bilirubin, total cholesterol, and triglycerides and a significant decrease $(\mathrm{p}<0.01)$ in total protein and plasma reduced glutathione in paracetamol-treated animals from those of the control group. Administration of $U$. lactuca polyphenols fraction $(50,100$, and $200 \mathrm{mg} / \mathrm{kg}$ ) decreased the reduced levels of AST, ALT, ALP, LDH, $\gamma$-GT, total bilirubin, total cholesterol, and triglycerides in a dose-dependent manner $(p<0.01)$. The levels of total protein and plasma reduced 
Table 1: Effect of Ulva lactuca polyphenols fraction on serum marker enzymes, protein, bilirubin, and reduced glutathione

\begin{tabular}{|c|c|c|c|c|c|c|}
\hline Parameters & Group I & Group II & Group III & Group IV & Group V & Group VI \\
\hline ALT (IU/L) & $48.50 \pm 2.09$ & $161.00 \pm 7.26^{\mathrm{a}^{*}}$ & $52.17 \pm 1.92^{b^{*}}$ & $65.00 \pm 3.07^{\mathrm{b}^{*}}$ & $58.00 \pm 2.74^{\mathrm{b}^{*}}$ & $52.83 \pm 2.49^{\mathrm{b}^{*}}$ \\
\hline AST (IU/L) & $82.00 \pm 3.71$ & $213.67 \pm \pm 10.45^{a^{*}}$ & $84.83 \pm 4.13^{b^{*}}$ & $111.83 \pm 5.37^{\mathrm{b}^{*}}$ & $99.83 \pm \pm 4.79^{\mathrm{b}^{*}}$ & $90.83 \pm 4.25^{\mathrm{b}^{*}}$ \\
\hline $\operatorname{ALP}(\mathrm{IU} / \mathrm{L})$ & $135.00 \pm 6.60$ & $291.33 \pm 11.08^{\mathrm{a}^{*}}$ & $139.50 \pm 6.61^{\mathrm{b}^{*}}$ & $181.83 \pm 9.52^{\mathrm{b}^{*}}$ & $162.33 \pm 8.50^{\mathrm{b}^{*}}$ & $147.50 \pm 7.23^{\mathrm{b}^{*}}$ \\
\hline LDH (IU/L) & $110.33 \pm 5.74$ & $182.17 \pm 8.69^{a^{*}}$ & $112.67 \pm 5.36^{\mathrm{b}^{*}}$ & $140.00 \pm 7.30^{\mathrm{b}^{*}}$ & $125.00 \pm 6.52^{\mathrm{b}^{*}}$ & $113.67 \pm 5.86^{b^{*}}$ \\
\hline$\gamma$-GT (IU/L) & $3.18 \pm 0.15$ & $6.58 \pm 0.31^{\mathrm{a}^{*}}$ & $3.25 \pm 0.17^{\mathrm{b}^{*}}$ & $4.17 \pm 0.31^{\mathrm{b}^{*}}$ & $3.72 \pm 0.28^{\mathrm{b}^{*}}$ & $3.38 \pm 0.18^{b^{*}}$ \\
\hline Total bilirubin (mg/dL) & $0.78 \pm 0.04$ & $2.48 \pm 0.13^{\mathrm{a}^{*}}$ & $0.80 \pm 0.04^{\mathrm{b}^{*}}$ & $1.02 \pm 0.06^{\mathrm{b}^{*}}$ & $0.90 \pm 0.05^{\mathrm{b}^{*}}$ & $0.82 \pm 0.05^{b^{*}}$ \\
\hline Total protein $(\mathrm{g} / \mathrm{dL})$ & $7.33 \pm 0.35$ & $5.03 \pm 0.26^{\mathrm{a}^{*}}$ & $7.25 \pm 0.30^{\mathrm{b}^{*}}$ & $5.80 \pm 0.29^{b^{*}}$ & $6.50 \pm 0.33^{\mathrm{b}^{*}}$ & $7.23 \pm 0.39^{b^{*}}$ \\
\hline Total cholesterol (g/dL) & $96.33 \pm 4.33$ & $200.17 \pm 8.98^{a^{*}}$ & $101.33 \pm 5.22^{\mathrm{b}^{*}}$ & $130.50 \pm 5.73^{\mathrm{b}^{*}}$ & $116.50 \pm 5.12^{b^{*}}$ & $105.83 \pm 4.37^{\mathrm{b}^{*}}$ \\
\hline Triglycerides (g/dL) & $86.33 \pm 4.09$ & $286.50 \pm 10.16^{\mathrm{a}^{*}}$ & $89.00 \pm 4.55^{b^{*}}$ & $115.00 \pm 6.19^{\mathrm{b}^{*}}$ & $102.67 \pm 5.53^{\mathrm{b}^{*}}$ & $93.33 \pm 4.78^{\mathrm{b}^{*}}$ \\
\hline Reduced glutathione $(\mathrm{mg} / \mathrm{dL})$ & $32.00 \pm 1.31$ & $17.50 \pm 0.98^{\mathrm{a}^{*}}$ & $30.83 \pm 1.21^{\mathrm{b}^{*}}$ & $22.67 \pm 0.99^{\mathrm{b}^{*}}$ & $25.50 \pm 1.10^{b^{*}}$ & $28.33 \pm 1.22^{\mathrm{b}^{*}}$ \\
\hline
\end{tabular}

Group I - Control; Group II - PCM; Group III - PCM+Silymarin; Group IV - PCM+ULPF 50 mg/kg; Group V - PCM+ULPF 100 mg/kg; Group VI - PCM+ULPF

$200 \mathrm{mg} / \mathrm{kg}$. The observations are given as Mean \pm SEM, $\mathrm{n}=6$; ${ }^{*} \mathrm{p}<0.01$; ${ }^{\mathrm{G} G r o u p ~ I ~ v e r s u s ~ G r o u p ~ I I ; ~}{ }^{\mathrm{b}}$ Group II versus Groups III, IV, V, and VI. PCM: Paracetamol; ULPF: Ulva

lactuca polyphenols fraction, ALT: Alanine aminotransferase, AST: Aspartate aminotransferase, ALP: Alkaline phosphatase, LDH: Lactate dehydrogenase, $\gamma$-GT: $\gamma$-Glutamyl transferase

Table 2: Effect of Ulva lactuca polyphenols fraction on liver homogenate reduced glutathione and antioxidant enzymes

\begin{tabular}{|c|c|c|c|c|c|c|}
\hline Parameters & Group 1 & Group 2 & Group 3 & Group 4 & Group 5 & Group 6 \\
\hline $\begin{array}{l}\text { Liver reduced glutathione }(\mathrm{mg} / 100 \mathrm{~g} \text { wet } \\
\text { tissue) }\end{array}$ & $48.50 \pm 2.52$ & $21.00 \pm 1.10^{\mathrm{a}^{*}}$ & $47.50 \pm 2.13^{\mathrm{b}^{*}}$ & $35.17 \pm 1.94^{\mathrm{b}^{*}}$ & $39.33 \pm 2.17^{b^{*}}$ & $43.67 \pm 2.14^{\mathrm{b}^{*}}$ \\
\hline 1Superoxide dismutase & $8.25 \pm 0.45$ & $4.30 \pm 0.23^{\mathrm{a}^{*}}$ & $8.02 \pm 0.46^{b^{*}}$ & $6.18 \pm 0.39^{b^{*}}$ & $6.93 \pm 0.43^{\mathrm{b}^{*}}$ & $7.70 \pm 0.24^{\mathrm{b}^{*}}$ \\
\hline 2Catalase & $57.50 \pm 2.20$ & $24.83 \pm 1.24^{\mathrm{a}^{*}}$ & $55.50 \pm 2.92^{b^{*}}$ & $41.17 \pm 1.89^{\mathrm{b}^{*}}$ & $46.17 \pm 2.12^{\mathrm{b}^{*}}$ & $51.33 \pm \pm 2.45^{\mathrm{b}^{*}}$ \\
\hline 3Glutathione peroxidase & $8.73 \pm 0.41$ & $4.35 \pm 0.24^{\mathrm{a}^{*}}$ & $8.42 \pm 0.39^{\mathrm{b}^{*}}$ & $6.12 \pm 0.38^{\mathrm{b}^{*}}$ & $6.85 \pm 0.43^{\mathrm{b}^{*}}$ & $7.62 \pm 0.38^{\mathrm{b}^{*}}$ \\
\hline
\end{tabular}

Group I - Control; Group II - PCM; Group III - PCM+Silymarin; Group IV - PCM+ULPF 50 mg/kg; Group V- PCM+ULPF 100 mg/kg; Group VI- PCM+ULPF 200 mg/kg. 1Superoixde dismutase is expressed as $50 \%$ inhibition of epinephrine autoxidation/min $/ \mathrm{mg}$ protein. 2Catalase is expressed as $\mu \mathrm{moles}$ of $\mathrm{H} 2 \mathrm{O} 2 \mathrm{decomposed} / \mathrm{min} /$ mg protein. ${ }^{3}$ Glutathione peroxidase is expressed as $\mu$ moles of glutathione oxidized $/ \mathrm{min} / \mathrm{mg}$ protein. The observations are given as Mean $\pm \mathrm{SEM}$, $\mathrm{n}=6$; ${ }^{*} \mathrm{p}<0.01 ;{ }^{\mathrm{a}} \mathrm{Group} \mathrm{I}$ versus Group II; ${ }^{b}$ Group II versus Groups III, IV, V, and VI. PCM: Paracetamol; ULPF: Ulva lactuca polyphenols fraction

glutathione were increased significantly by the administration of U. lactuca polyphenols fraction in a dose-dependent manner. Silymarin, the reference drug restored the altered levels of enzymes significantly $(\mathrm{p}<0.01)$ (Table 1).

Hypoalbuminemia is very common in advanced chronic liver diseases. Hence, decrease in total protein content can be considered as a useful index of the severity of cellular dysfunction in chronic liver diseases. The decreased level of total proteins recorded in the serum of paracetamol-treated rats suggests the severity of hepatotoxicity. The restoration of near normalcy in total protein content of the serum of $U$. lactuca polyphenols fraction treated rats further elucidates the hepatoprotective effect of $U$. lactuca polyphenols fraction.

Decreased activities of the antioxidant enzymes, superoxide dismutase, catalase, and glutathione peroxidase observed in the liver homogenate of paracetamol-treated rats indicate the extensive liver damage induced by the hepatotoxin $(p<0.01)$. The tendency of these enzymes to return to near normalcy in U. lactuca polyphenols fraction administered groups $(50,100$, and $200 \mathrm{mg} / \mathrm{kg})$ in a dose-dependent manner is a clear indication of hepatoprotective effect of $U$. lactuca polyphenols fraction extract through antioxidant mechanism $(\mathrm{p}<0.01)$ (Table 2).

Experimental and epidemiological studies indicate the involvement of oxidative stress in the pathogenesis and progression of many chronic diseases [33]. It is known that oxygen, essential for maintaining life, sometimes becomes toxic and results in the generation of most aggressive agents such as reactive oxygen species (ROS). The high reactivity of ROS may activate a host of disorders in the body resulting in tissue damage and necrosis in many instances [34]. The body has an effective mechanism to prevent and neutralize the free radical-induced damage. This is achieved by a set of endogenous antioxidant enzymes such as superoxide dismutase, catalase, and glutathione peroxidase. When the equilibrium between ROS production and antioxidant defense is lost, oxidative stress results, which through a series of events, deregulate the cellular functions, leading to various pathological conditions [35].

It is probable that natural antioxidants strengthen the endogenous antioxidant defense from ROS damage and restore the optimal equilibrium by neutralizing the reactive species. They are gaining enormous importance by virtue of their critical role in disease prevention.

\section{CONCLUSION}

It can be said that $U$. lactuca polyphenols fraction has exhibited a liver protective effect against paracetamol-induced hepatotoxicity and possessed antioxidant activities. Thus, U. lactuca, commonly used as a food and as a traditional medicinal agent, is found to have hepatoprotective effect and antioxidant activities. U. lactuca is a seaweed, but it is proven to possess immense potential by this study. Efforts are in progress to isolate and purify the active principle involved in the hepatoprotective efficacy of this marine alga.

\section{ACKNOWLEDGMENT}

The authors are thankful to the management of Adhiparasakthi College of Arts and Science (Autonomous), Kalavai, India, for providing the facilities.

\section{AUTHORS' CONTRIBUTIONS}

Ravindran NT designed study project and performed experiments. $\mathrm{He}$ was also involved in manuscript editing and finalization. Mohamed Sadiq A designed study project, contributed in experiment finalization and implementation, manuscript editing, and finalization.

\section{CONFLICTS OF INTEREST}

The authors declare that they have no conflicts of interest. 


\section{REFERENCES}

1. Wolf PL. Biochemical diagnosis of liver disease. Indian J Clin Biochem 1999; 14:59-90.

2. Anup S, Shivanandappa T. Hepatoprotective effect of the root extract of Decalepis hamiltonii against carbon tetrachloride-induced oxidative stress in rats. Food Chem 2010;118:411-7.

3. Ahmad I, Aqil F, Owais M. Modern Phytomedicine: Turning Medicinal Plants into Drugs. New York: John Wiley and Sons; 2006.

4. Liu L, Heinrich M, Myers S, Dworjanyn SA. Towards a better understanding of medicinal uses of the brown seaweed Sargassum in traditional Chinese medicine: A phytochemical and pharmacological review. J Ethnopharmacol 2012;142:591-619.

5. Chakraborty K, Paulraj R. Sesquiterpenoids with free radical scavenging properties from marine macroalga Ulva fasciata Delile. Food Chem 2010;122:31-41.

6. Gupta S, Abu-Ghannam N. Recent developments in the application of seaweeds or seaweed extracts as a means for enhancing the safety and quality attributes of foods. Innov Food Sci Emerg Technol 2011;12:600-9.

7. Kim IH, Lee DG, Lee $\mathrm{SH}$, Ha JM, Ha BJ, Kim BJ, et al. Antibacterial activity of Ulva lactuca against Methicillin-resistant Staphylococcus aureus (MRSH). Biotechnol Bioprocess Eng 2007;12:579-82.

8. Meenakshi S, Gnanambigai DM, Mozhi ST, Arumugam M, Balasubramanian T. Total flavanoid and in vitro antioxidant activity of two seaweeds of Rameshwaram coast. Glob J Pharmacol 2009;3:59-62.

9. Sathivel A, Raghavendran HR, Devaki T. Hepatoprotective nature of seaweeds (Ulva lactuca/Gracilaria edulis) against liver injury induced by $\mathrm{D}$-Galactosamine/endotoxin in rats. Seaweed Res Utlin 2003;25:109-11.

10. Hassan S, El-Twab SA, Hetta M, Mahmoud B. Improvement of lipid profile and antioxidant of hypercholesterolemic albino rats by polysaccharides extracted from the green alga Ulva lactuca Linnaeus. Saudi J Biol Sci 2011;18:333-40.

11. Pushparaj A, Raubbin RS, Balasankar T. Antibacterial activity of Kappaphycus alvarezii and Ulva lactuca extracts against humanpathogenic bacteria. Int J Curr Microbiol Appl Sci 2014;3:432-6.

12. Mahmoud HM, Hussein UL. Suppression of N-nitrosodiethylamine induced oxidative renal toxicity by sulphatedpolysaccharide and aqueous extract of Ulva lactuca in rats. Int J Pharm Pharm Sci 2014;6:248-53.

13. Suganthy N, Karutha Pandian S, Pandima Devi K. Neuroprotective effect of seaweeds inhabiting South Indian coastal area (Hare Island, Gulf of Mannar marine biosphere reserve): Cholinesterase inhibitory effect of Hypnea valentiae and Ulva reticulata. Neurosci Lett 2010;468:216-9.

14. Reka P, Banu AT, Seethalakshmi M. Alpha amylase and alpha glucosidase inhibition activity of selected edible seaweeds from south coast area of India. Int J Pharm Pharm Sci 2017;9:64-8.

15. Heo SJ, Cha SH, Lee KW, Jeon YJ. Antioxidant activities of red alga from Jeju Island. Alga 2006;21:149-56.
16. Ecobichon DJ. The Basis of Toxicology Testing. $2^{\text {nd }}$ ed. New York: CRC Press; 1997. p 43-60.

17. Reitman S, Frankel S. A colorimetric method for the determination of serum glutamic oxalacetic and glutamic pyruvic transaminases. Am J Clin Pathol 1957;28:56-63.

18. King EJ, Armstrong AR. Determination of serum and bile phosphatase activity. Can Med Assoc J 1934;31:56-63.

19. King J. The hydrolase and alkaline phosphatase. In: Practical Clinical Enzymology. London: Nostrand Co. Ltd.; 1965. p. 191.

20. Rosalki SB, Rau D. Serum -glutamyl transpeptidase activity in alcoholism. Clin Chim Acta 1972;39:41-7.

21. Malloy HT, Evelyn EA. The determination of bilirubin with photoelectric colorimeter. J Biol Chem 1937;119:481-5.

22. Lowry OH, Rosebrough NJ, Farr AL, Randall RJ. Protein measurement with the folin phenol reagent. J Biol Chem 1951;193:265-75.

23. Parekh AC, Jung DH. Cholesterol determination with ferric acetateuranium acetate and sulfuric acid-ferrous sulfate reagents. Anal Chem 1970;42:1423-7.

24. Foster LB, Dunn RT. Stable reagents for determination of serum triglycerides by a colorimetric hantzsch condensation method. Clin Chem 1973;19:338-40.

25. Moron MS, Depierre JN, Mannervik B. Levels of glutathione, glutathione reductase and glutathione-S-transferase activity in rat lung and liver. Biochim Biophys Acta 1979;582:67-78.

26. Misra HP, Fridovich I. The role of superoxide anion in the autoxidation of epinephrine and a simple assay for superoxide dismutase. J Biol Chem 1972;247:3170-5.

27. Takahara S, Hamilton BH, Neel JV, Kobara TY, Ogura Y, Nishimiua ET. Hypocatalasemia, a new genetic carrier state. J Clin Invest 1960;39:610-9.

28. Rortruck JT, Pope AL, Ganther HE, Swanson AB. Selenium: Biochemical roles as a component of glutathione peroxidase. Science 1973;179:588-90.

29. Larrey D. Drug induced liver disease. J Hepatol 2003;32:77-88.

30. Watkins PB, Seef LB. Drug induced liver injury: Summary of a single topic clinical research committee. Hepatology 2006;43:618-31.

31. Mitra SK, Venkataranganna MV, Sundaram R, Gopumadhavan S. Protective effect of HD-03, a herbal formulation against various hepatotoxic agents in rats. J Ethnolpharmacol 1998;63:181-6.

32. Dwivedi Y, Rastogi R, Garg NK, Dhandan DM. Prevention of paracetamol-induced hepatic damage in rats by picrolir, the standardized active fraction from Picorhiza kurrao. Phytother Res 1991;5:115-9.

33. Tewari S, Gupta V, Bhattacharya S. Comparative study of antioxidant potential of tea with and without additives. Indian J Physiol Pharmacol 2000;44:215-9.

34. Prasad VS, Venkatachalam SR, Chander R, Thomas P. Dietary antioxidants-natural defense against disease. Aryavaidyan 1999; $12: 149-58$.

35. Bandyopadhyay U, Das D, Banerjee KR. Reactive oxygen species: Oxidative damage and pathogenesis. Curr Sci 1999;77:658-66. 